https://doi.org/10.17816/MAJ191S1109-111

\title{
ALTERATIONS IN THE MRNA EXPRESSION OF D2 DOPAMINE RECEPTOR SPLICE VARIANTS AS POSSIBLE MECHANISM OF PREFRONTAL DYSFUNCTION AFTER EARLY-LIFE IMMUNE CHALLENGE
}

\author{
A.P. Schwarz ${ }^{1}$, A.N. Trofimov ${ }^{2}$, A.M. Ischenko ${ }^{3}$, O.E. Zubareva ${ }^{4}$, V.M. Klimenko ${ }^{2}$
}

${ }^{1}$ Multidisciplinary Laboratory of Neurobiology, I.M. Sechenov Institute of Evolutionary Physiology and Biochemistry, Russian Academy of Sciences, Saint Petersburg, Russia;

${ }^{2}$ Laboratory of Neurobiology of the Brain Integrative Functions, I.P. Pavlov Department of Physiology, Institute of Experimental Medicine, Saint Petersburg, Russia;

${ }^{3}$ Laboratory of Protein Biochemistry, Research Institute of Highly Pure Biopreparations, Saint Petersburg, Russia;

${ }^{4}$ Laboratory of Molecular Mechanisms of Neuronal Interactions, I.M. Sechenov Institute of Evolutionary

Physiology and Biochemistry, Russian Academy of Sciences, Saint Petersburg, Russia

\section{ИЗМЕНЕНИЕ СОДЕРЖАНИЯ ОТДЕЛЬНЫХ СПЛАЙС-ВАРИАНТОВ МРНК D2 РЕЦЕПТОРА ДОФАМИНА КАК ВОЗМОЖНЫЙ МЕХАНИЗМ ДИСФУНКЦИИ ПРЕФРОНТАЛЬНОЙ КОРЫ ВСЛЕДСТВИЕ АКТИВАЦИИ ИММУННОЙ СИСТЕМЫ B PАННЕМ ВОЗРАСТЕ}

\author{
А.П. Швари , А.Н. Трофимов ${ }^{2}$ А.М. Ищенко ${ }^{3}$, О.Е. Зубарева ${ }^{4}$, В.М. Клименко 2 \\ ${ }^{1}$ Междисциплинарная лаборатория нейробиологии, \\ ФГБУН «Институт эволюционной физиологии и биохимии им. И.М. Сеченова РАН», Санкт-Петербург; \\ 2 Лаборатория нейробиологии интегративных функций мозга Физиологического отдела \\ им. И.П. Павлова, ФГБОУ «Институт экспериментальной медицины», Санкт-Петербург; \\ 3 Лаборатория биохимии белка, ФГУП «Государственный научно-исследовательский институт \\ особо чистых биопрепаратов» ФМБА, Санкт-Петербург; \\ 4 Лаборатория молекулярных механизмов нейрональных взаимодействий, \\ ФГБУН «Институт эволюционной физиологии и биохимии им. И.М. Сеченова РАН», Санкт-Петербург
}

Schwarz@gmail.com

Various detrimental factors during early life may affect CNS development and increase risk of neuropsychiatric symptoms in later life. Disruption in brain dopaminergic system maturation is believed to be one of the mechanism of different neurodevelopmental disordrers. In this article we review behavioral peculiarities and changes of prefrontal D2 dopamine receptor splice variants (D2S and D2L) expression in rats after chronic experimental increase of proinflammatory cytokine interleukin(IL)- $1 \beta$ during $3^{\text {rd }}$ week of life. Early life IL- $1 \beta$ treatment produce long lasting working memory deficit originating in juvenile adult animals. Elevation of IL-1 $\beta$ during $3^{\text {rd }}$ week of life also affect developmental expression of D2 dopamine receptor mRNAs leading to increased D2S/D2L ratio in the medial prefrontal cortex of adolescent but not adult rats. Early life IL-1 $\beta$ treatment cancelled the learning-induced D2L mRNA downregulation during active avoidance conditioning in adult rats. Thus, dysregulation of expression of distinct D2 dopamine receptor splice variants within medial prefrontal cortex is supposed to be implicated in cognitive decline caused by early life immune challenge.

Keywords: early life; proinflammatory cytokines; interleukin-1 $\beta$; cognitive deficit; medial prefrontal cortex.

Негативные факторы в раннем онтогенезе могут нарушать развитие ЦНС и вести к повышенному риску возникновения нерно-психических симптомов в дальнейшей жизни. Одним из механизмов таких нарушений считается повреждение процессов созревания дофаминергической системы. В данной работе приведен краткий обзор поведенческих нарушений и изменений содержания в префронтальной коре мозга изоформ D2 рецептора дофамина (D2S и D2L) у крыс после хронического повышения уровня

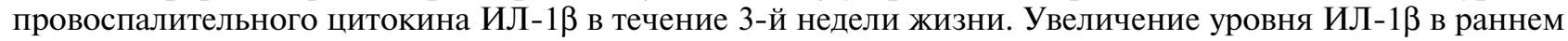
возрасте приводит к долговременному дефициту рабочей памяти, возникающему у неполовозрелых животных, а также нарушает возрастную динамику экспрессии гена D2 рецептора дофамина, приводя к повышенному соотношению D2S/D2L в медиальной префронтальной коре крыс-подростков, но не взрослых животных. Введение ИЛ-1 $\beta$ в раннем возрасте отменяет реакцию снижения содержания мРНК D2L рецептора, связанную с процессом выработки условного рефлекса активного избегания, в данной области коры мозга взрослых крыс. Таким образом, дизрегуляция экспрессии гена D2 рецептора дофамина на уровне отдельных сплайс-вариантов может быть вовлечена в механизмы формирования когнитивного дефицита вследствие активации иммунной системы в раннем постнатальном онтогенезе.

Ключевые слова: ранний постнатальный онтогенез; провоспалительные цитокины; интерлейкин- $1 \beta$; когнитивные дисфункции; медиальная префронтальная кора. 
Proinflammatory cytokine interleukin(IL)- $1 \beta$ is well known to modulate brain functions in health and disease. Its elevation due to various pathological conditions, such as infectious diseases, hypoxia, different kinds of stress, etc., results in sickness behavior symptoms, e.g. lack of food and sexual motivation, sleeping, motor hypoactivity, as well as impairs memory and hippocampal neuroplasticity mechanisms [1]. However, low level of IL-1 $\beta$ is essential for normal memory processes in adult brain and plays an important role in the CNS development [1]. Increased levels of IL-1 $\beta$ in the blood and CNS during vulnerable periods of early life is well described to be detrimental factor for the brain maturation [1]. A number of studies have revealed that early life heightening of IL- $1 \beta$ produces behavioral dysfunctions in later life $[1,2]$, which may be associated with disruptions of the brain dopaminergic system development.

Here we describe a possible role of D2 dopamine receptor alternative splicing in the formation of cognitive decline after early-life IL- $1 \beta$ elevation. D2 dopamine receptors (DRs) are known to be implicated in different neuropsychiatric pathologies [3]. Short (D2S) and long (D2L) variants of D2 receptor mRNA are produced by alternative splicing and differ by downstream intracellular signal pathways and synaptic localization: the D2L receptors are mainly distributed postsynaptically, while D2S receptors have predominant presynaptic localization [3]. The two isoforms of D2 DRs play different roles in the regulation of cognitive functions as human intronic single nucleotide polymorphisms (SNPs) affecting alternative splicing of D2 DR mRNA have been shown to modulate prefrontal cortical activity and working memory [4].

We have demonstrated that D2S mRNA expression and D2S/D2L ratio was strongly downregulated within medial prefrontal cortex during adolescence in normal rat development. Since adolescence is a critical period for behavior maturation, any abnormalities of prefrontal D2S/D2L mRNA ratio during this period may be one of the mechanisms underlying increased susceptibility of adolescent brain for different kinds of harmful events. Thus, we hypothesized that early-life factors inducing long lasting behavioral disruptions might affect developmental changes in the prefrontal expression of distinct D2 dopamine receptor isoforms.

Chronic early-life IL-1 $\beta$ treatment has been shown to induce the long lasting deficit of working memory: rats injected with IL- $1 \beta$ during the $3^{\text {rd }}$ week of postnatal life demonstrated fewer spontaneous alternations in the Y-maze compared to control when tested in juvenile (P25), adolescent (P42-47) or adult (P75-90) age [5]. Such working memory impairments were found to be accompanied by altered developmental mRNA expression of D2 dopamine receptor splice variants within the medial prefrontal cortex [5]. We have found that neonatal IL- $1 \beta$ exposure were able to exaggerate developmental D2S mRNA downregulation within the medial prefrontal cortex and diminished the decrease in D2S/D2L mRNA ratio during adolescence [5]. It is worth mentioning that most prominent effects of early-life IL-1 $\beta$ treatment were observed during adolescent period not only on the prefrontal D2S/D2L mRNA expression but also on exploratory behavior in the Open field arena [6].

Despite of altered D2S/D2L mRNA expression ratio in adolescent period, adult rats after neonatal IL-1 $\beta$ treatment did not differ from controls in basal mRNA level of D2 DR isoforms. Our previous studies have shown that chronic treatment with moderately pyrogenic doses of IL- $1 \beta$ during the $3^{\text {rd }}$ week of life impaired learning ability in the Active avoidance paradigm in adult animals [2]. It should be noticed, that chronic early-life IL-1 $\beta$ treatment abrogated the learning-induced D2L mRNA downregulation within the medial prefrontal cortex in adulthood, while prefrontal D2S mRNA levels negatively correlated with the learning ability in control but not IL-1 $\beta$-treated rats [7].

These data indicate that early-life proinflammatory challenge accompanied by chronic IL- $1 \beta$ elevation may produce long lasting disturbances in prefrontal neuroplasticity mechanisms, particularly dysregulation of distinct D2 dopamine receptor isoform mRNA expression.

Supported by RFBR project 17-04-02116.

\section{References}

1. Zubareva OE, Klimenko VM. Increases in proinflammatory cytokine levels at early ages as a risk factor for the development of nervous and mental pathology. Neuroscience and Behavioral Physiology. 2013;43(4):535-541.

2. Zubareva OE, Shcherbakova KP, Kalemenev SV, et al. Impairments to conditioned reflex activity in adult rats after administration of interleukin- $1 \beta$ during early postnatal ontogeny. Neuroscience and Behavioral Physiology. 2013;43(2):210-213.

3. Beaulieu J-M, Espinoza S, Gainetdinov RR. Dopamine receptors - IUPHAR Review 13. British Journal of Pharmacology. 2015;172(1):1-23.

4. Zhang Y, Bertolino A, Fazio L, et al. Polymorphisms in human dopamine D2 receptor gene affect gene expression, splicing, and neuronal activity during working memory. Proc Natl Acad Sci US A. 2007;104(51):2055220557.

5. Schwarz AP, Rotov AY, Chuprina OI, et al. Developmental prefrontal mRNA expression of D2 dopamine receptor splice variants and working memory impairments in rats after early life Interleukin- $1 \beta$ elevation. Neurobiology of Learning and Memory. 2018;155:231-238. 
6. Zubareva OE, Eliseeva AP, Simbirtsev AS, Klimenko VM. The effects of proinflammatory cytokines on the formation of behavior in early postnatal ontogenesis. Neuroscience and Behavioral Physiology. 2006;36(4):367-372.

7. Schwarz AP, Trofimov AN, Zubareva OE, et al. Prefrontal mRNA expression of long and short isoforms of D2 dopamine receptor: Possible role in delayed learning deficit caused by early life interleukin-1 $\beta$ treatment. Behavioural Brain Research. 2017;333:118-122. 